\title{
Geographic variation and conservation of the Moustached Woodcreeper Xiphocolaptes falcirostris, an endemic and threatened species of north-eastern Brazil
}

\author{
JOSÉ MARIA CARDOSO DA SILVA and DAVID C. OREN
}

\section{Summary}

We correct the limits of the range and analyse the geographical variation of the Moustached Woodcreeper Xiphocolaptes falcirostris, an endemic species of north-eastern Brazil. A single, undated specimen of Moustached Woodcreeper from Posse, Goiás, in the Paranã River Valley was probably collected somewhere on the left bank of the São Francisco River. Analysis of the plumage variation and five body measurements indicates that it is not always possible to separate the populations of the Moustached Woodcreeper into the two subspecies currently recognized. In spite of this, given the importance of this bird as an indicator species for conservation, we suggest that the current recognition of the subspecies be maintained until genetic studies provide a definitive answer to this taxonomic question. Moustached Woodcreepers are particularly associated with patches of dry forest growing on rich soils in north-eastern Brazil. In the past decades, this type of vegetation has been drastically modified by human activities. Only an urgent plan to establish a network of reserves for tropical dry forests in north-eastern Brazil can prevent the complete destruction of this habitat and of its poorly known biological resources.

Nós corrigimos os limites da distribuição e analisamos a variação geográfica do Cochi-do-nordeste Xiphocolaptes falcirostris, uma espécie endêmica do Nordeste brasileiro. Um único espécime sem data de $X$. falcirostris coletado em Posse, Goiás, no vale do rio Paranã. foi provavelmente coletado em algum lugar na margem esquerda do vale do rio São Francisco. Análise da variação da plumagem e de cinco medidas do corpo indicam que não é sempre possível separar as populações de Cochi-do-nordeste em duas subespécies, tal como é feito atualmente. Apesar disso, em consideração à importância desse arapaçu como espécie indicadora, nós sugerimos que o Cochi-do-nordeste ainda seja considerado uma espécie com duas subespécies, até que essa questão taxonômica seja resolvida definitivamente através de estudos genéticos. Cochis-do-nordeste são particularmente associados com manchas de florestas secas crescendo sobre solos ricos no Nordeste brasileiro. Nas últimas décadas, este tipo de vegetação tem sido drasticamente modificado por atividades humanas. Nós sugerimos que somente um plano urgente visando o estabelecimento de um sistema de reservas para as florestas tropicais secas no nordeste do Brasil possa prevenir a completa destruição desse habitat e de seus pouco conhecidos recursos biológicos.

\section{Introduction}

The Moustached Woodcreeper Xiphocolaptes falcirostris is a large (c. $100 \mathrm{~g}$ ) but poorly known forest bird restricted to north-eastern Brazil (Pinto 1978, Ridgely 
and Tudor 1994). Known principally through the modest number of specimens deposited in natural history museum collections, few aspects of its natural history, geographical variation, and distribution have been studied (review in Collar et al. 1992). For example, the status of the two currently recognized subspecies of Moustached Woodcreeper, $X . f$. falcirostris (from Pernambuco, Ceará, Piauí, Maranhão and northeastern Bahia), and $X . f$. franciscanus (from western bank of the River São Francisco in the states of Bahia and Minas Gerais) are not well resolved, as this taxonomic arrangement was based on the study of only a few specimens, covering only part of the species's range (Teixeira 1990). More recently, the Moustached Woodcreeper has been included in both the Brazilian list of threatened animals (Bernardes et al. 1990) and the Red Data Book for American birds (Collar et al. 1992).

In this paper, we correct the range limits and analyse the geographical variation in plumage and body measurements of the Moustached Woodcreeper. Our main aim was to evaluate whether the current taxonomic division of this species into two subspecies is warranted. In addition, we discuss the status of the habitat of the Moustached Woodcreeper as well as propose some strategies to guarantee the conservation of this species and its habitat.

\section{Historical taxonomic review}

Xiphocolaptes $f$. falcirostris was described by Spix (1824) based on a single specimen from an unspecified locality. Hellmayr (1906) redescribed falcirostris in detail, including in it synonymous $X$. cinnamomeus Ridgway, whose type is a "trade skin" from Bahia. In his important work on the birds of north-eastern Brazil, Hellmayr (1929) included two more taxa as synonymies of falcirostris: $X$. promeropirhynchus iguatensis Cory, from Juá $\left(6^{\circ} 20^{\prime} \mathrm{S}, 39^{\circ} 25^{\prime} \mathrm{W}\right)$, near Iguatú, Ceará; and $X$. albicollis villanovae Lima, whose type is from Vila Nova da Rainha, currently called Senhor do Bonfim ( $\left.10^{\circ} 30^{\prime} \mathrm{S}, 40^{\circ} 10^{\prime} \mathrm{W}\right)$, Bahia. Hellmayr (1929) designated Oeiras ( $\left.7^{\circ} \mathrm{Oo} ' \mathrm{~S}, 42^{\circ} \mathrm{O} 5^{\circ} \mathrm{W}\right)$, Piaui, as type locality of falcirostris. Pinto and Camargo (1961) indicated that X. albicollis villanovae is not related to falcirostris, but to albicollis. New specimens collected recently in Bahia support Pinto's suggestion (J. M. C. S., unpubl. data).

Snethlage (1926) described franciscanus as a different species, based on a single specimen collected at Brejo Januária, (today Brejo do Amparo), Januária $\left(15^{\circ} 22^{\prime} \mathrm{S}, 44^{\circ} 25^{\prime} \mathrm{W}\right)$, Minas Gerais. In the original description, Snethlage compared franciscanus with $X$. albicollis bahiae Cory (whose type locality is Bahia, Macaco-Seco, near Andaraí, $12^{\circ} 4^{\prime} \mathrm{S}, 4^{\circ} 20^{\prime} \mathrm{W}$ ), and falcirostris, the two geographically closest forms. Based on the length and width of the bill as well as the plumage pattern of the crown, Snethlage associated franciscanus with falcirostris rather than with albicollis. In spite of this, both Pinto (1952) and Meyer de Schauensee (1966) suggested that franciscanus was merely a subspecies of albicollis, and Peters (1951) stated that franciscanus had uncertain affinities. Teixeira et al. (1989) also ignored Snethlage's comments and pointed out, as something new, the strong phenotypic similarity between franciscanus and falcirostris. Teixeira (1990), after an analysis based on seven specimens (two of franciscanus and five of falcirostris), considered franciscanus as a 
subspecies of falcirostris. According to Teixeira (1990) franciscanus differs from falcirostris by having: (a) whitish streaks of the breast narrower, (b) underparts strongly olivaceous-brown, and (c) rachis of the rectrices dark brown rather than light brown. In addition, Meyer de Schauensee (1970) and Ridgely and Tudor (1994) pointed out that franciscanus has a less streaked crown than falcirostris.

\section{Methods}

We examined 42 specimens including two juveniles of the Moustached Woodcreeper (Appendix) housed at the American Museum of Natural History, New York, U.S.A. (AMNH); Museu Nacional, Rio de Janeiro, Brazil (MNRJ); Museu Paraense Emílio Goeldi, Belém, Brazil (MPEG); and Museu de Zoologia da Universidade de São Paulo, São Paulo, Brazil (MZUSP). This is by far the largest series that has ever been examined in a taxonomic review of this species.

For each specimen we took the following body measurements (after Baldwin et al. 1931): wing (flattened), tail, exposed culmen, total culmen, and tarsus. We could not quantify most of the plumage characters, but we provide accurate descriptions of them when discussing their variation. The only plumage character that could be quantified was the width of white or buff streaks in the breast. For each specimen, we measured the five widest breast streaks and calculated the mean of these five measurements. We used this mean for statistical comparisons.

Before any analyses we grouped specimens into three discrete collection regions based on the proximity of localities (Figure 1): (a) northern, specimens collected in the states of Ceará, Paraiba, Pernambuco, Maranhão, and northern Piauí (commonly referred to falcirostris); (b) central, specimens collected in southern Piauí and northern Bahia (also referred to falcirostris), and (c) southern, specimens collected in central-western Bahia, on the left bank of the São Francisco River valley (specimens generally referred to franciscanus). We pooled males and females because no significant difference in the five body measurements was found between sexes ( $t$-test, $P<0.05$ ) or in the width of the breast streaks.

Each body measurement was log transformed ( $\log 10)$ to equalize variance. We used analyses of variance (ANOVA) to compare body measurements among populations. If significant differences were found, then we used Tukey's test (Zar 1984) to identify between which populations significant differences exist. To compare populational differences in width of the breast streaks, we used the Kolmogorov-Smirnov two-sample test (Zar 1984). To evaluate how useful the body measurements are to separate franciscanus from falcirostris, we applied linear discriminant analysis with cross-validation using the software MINITAB 8.o (Minitab Inc. 1991). The cross-validation procedure is a technique used to compensate for an optimistic apparent error rate (AER). AER tends to be optimistic because the data being classified are the same data used to build the classification function (Minitab Inc. 1991). When describing the colour of plumage characters, we used names and numbers (in parentheses) according to Smithe $(1974,1981)$. 


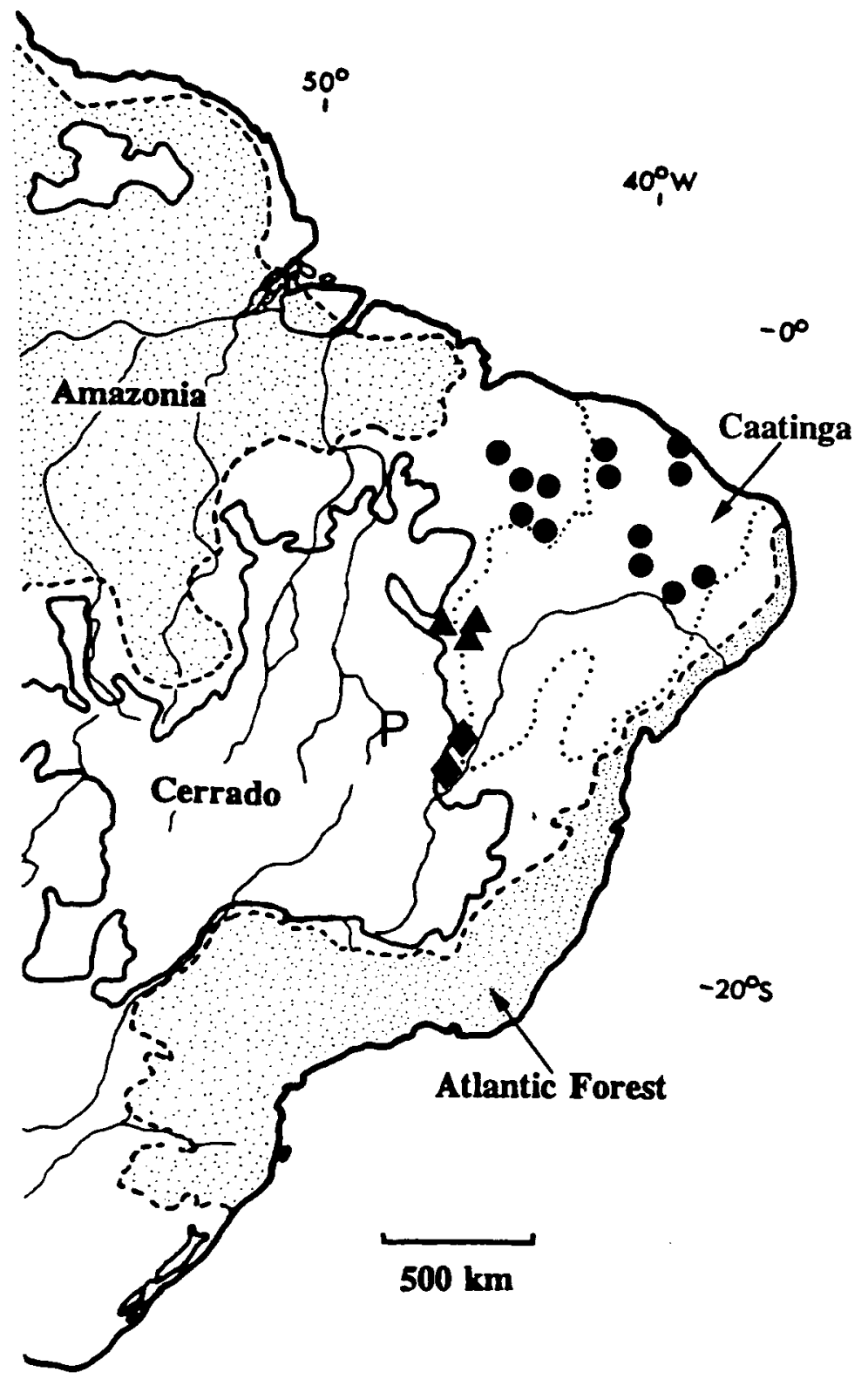

Figure 1. Distribution of the Moustached Woodcreeper in north-eastern Brazil. Dots, northern region; triangles, central region; rhomboids, southern region. Limits between major ecological regions are from Ab'Saber (1977). Stippled areas are regions dominated by tropical humid forests. $P$ indicates the location of the Paranã River valley. 


\section{Results}

\section{Distribution}

Collar et al. (1992) summarized all records then available for the Moustached Woodcreeper. They included one record of this species for Posse $\left(14^{\circ} 05^{\prime} \mathrm{S}\right.$, $46^{\circ} 28^{\prime} \mathrm{W}$ ), Goiás, based on an undated specimen (MNRJ 13822) collected by R. Pfrimer (Teixeira 1990) (Figure 1). However, this single record is probably erroneous, like other records based on specimens of this same collector. Very often Pfrimer did not include the collection date on his labels. He also labelled several specimens with localities without any precision (e.g., Goiás or Serra Geral). To add more confusion, the zoologist Alípio de Miranda Ribeiro labelled some specimens collected by the Rondon Commission that explored Mato Grosso, Mato Grosso do Sul and Rondonia between 1908 and 1915 (Sick 1985), as if they had been collected by Pfrimer. Some conspicuous cases of errors (Silva 1989) are two specimens of Pyrrhura rhodogaster (MNRJ 3,632 and 3,633), a species endemic to the region between the Madeira and Xingu Rivers (Pinto 1978), labelled as collected at Palmas, Goiás; and two specimens of Pionopsitta barrabandi (MNRJ 3,979 and 3,980), a species restricted to western Amazonia (Forshaw 1978), labelled as collected at Espírito Santo do Peixe, Goiás (today called Peixe, in the state of Tocantins).

The strongest evidence for the hypothesis that Pfrimer's specimen of falcirostris is mislabelled is that the White-throated Woodcreeper X. albicollis has been collected in São Domingos, Fazenda CIPASA (c. $13^{\circ} 35^{\prime} \mathrm{S} 46^{\circ} 49^{\prime} \mathrm{W}$ ), a few kilometres north of Posse (two specimens at MPEG). So far, there exist no records of sympatric occurrence of any two species of the genus Xiphocolaptes and during fieldwork carried out by one of us (Silva) to study the avifauna of the dry forests of the Rio Paranã valley (which includes both Posse and São Domingos), only White-throated Woodcreepers have been found. Since Pfrimer also collected birds in the São Francisco River valley in Bahia (Silva 1989), a region definitely inhabited by Moustached Woodcreepers, we suggest that Pfrimer's specimen supposedly from Goiás is in fact from Bahia.

\section{Plumage variation}

Specimens collected in the northern and central regions show strong variation in plumage. The variation includes (a) the general coloration of the underparts, which varies from light brown with reddish tones to dark brown; (b) the colour of the rachis of the rectrices, which appears also to change over time following collection; and (c) the throat coloration, which can vary from completely white to strongly washed with buff. The crown of all specimens is always streaked, although the streaks may vary conspicuously in width and colour. Immatures in both regions have black streaks on the central feathers of the belly, a characteristic that may be retained partially by some adults.

The variation in the series of specimens collected in the southern region appears to be less than that shown by specimens of the northern and central regions. There is, however, a seasonal component (that could not be evaluated in the series from the northern and central regions due to the small samples) that 


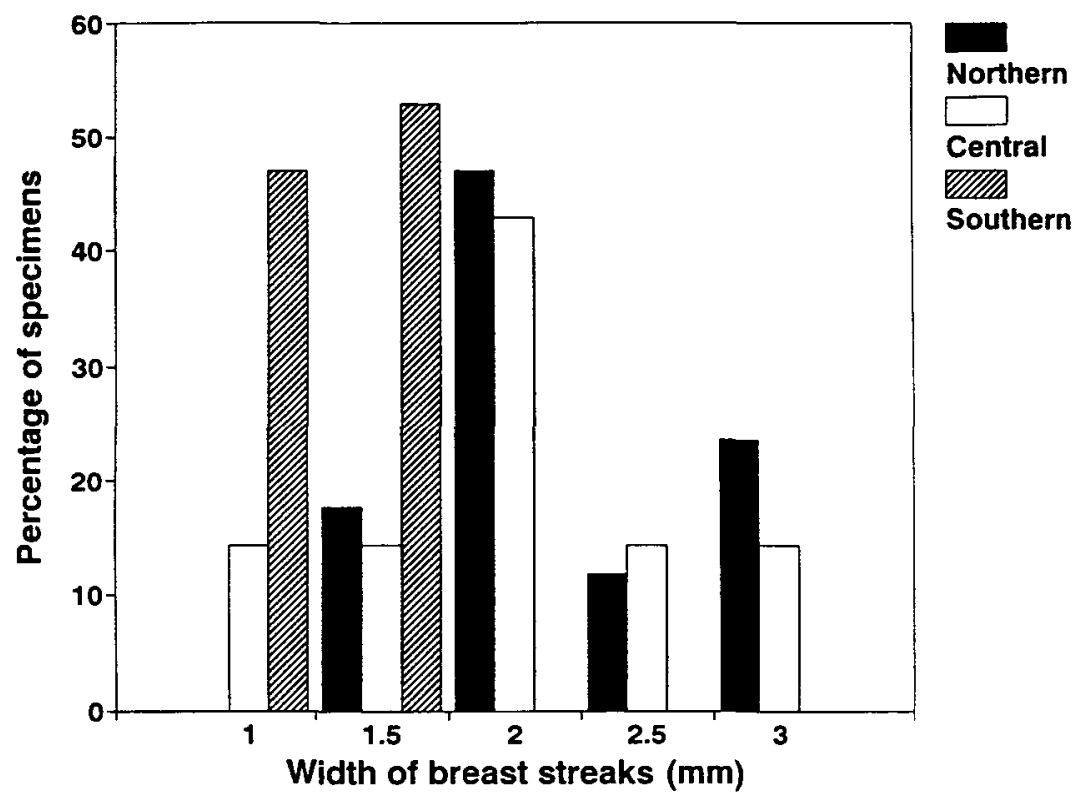

Figure 2. Distribution of the percentage of specimens of the Moustached Woodcreeper by categories of width of breast streaks and regions. Number of specimens per region: northern (17), central (7) and southern (17).

needs to be taken into account. The series of eight specimens from Itacarambi $\left(15^{\circ} \mathrm{O} 8^{\prime} \mathrm{S}, 44^{\circ} \mathrm{O} 4^{\prime} \mathrm{W}\right)$, Minas Gerais, was prepared in October, when the individuals were in breeding condition (J.M.C.S., unpubl.data). The specimens in this series are all highly worn. The series of nine specimens from Coribe $\left(13^{\circ} 45^{\prime} \mathrm{S}, 44^{\circ} 28^{\prime} \mathrm{W}\right)$ was prepared in May, when individuals were not reproductive, and the plumage new, following post-reproductive moult. The principal difference between these two series is that the specimens from Coribe are generally darker. In addition, the rectrices and rump of the specimens from Coribe are Warm Sepia (221A) and Kingfisher Rufous (240), respectively, instead of Antique Brown (37) and Verona Brown $(223 \mathrm{~B})$ as in the Itacarambi specimens. This suggests that there is a certain amount of seasonal variation in plumage coloration of specimens from the southern region. Nevertheless, the coloration of the rachis of the rectrices varies aseasonally and individuals with light-coloured as well as dark rachi exist in both series. The crown of the specimens $(n=18)$ may be without (11.1\%), with few streaks $(55.5 \%)$, or with several streaks $(33.4 \%)$. These last specimens have crown colour similar to the pattern found in most of the specimens from northern and central regions. An immature individual collected at Itacarambi has black bars in the middle of the belly, a pattern similar to that found in immatures of the northern and central regions.

The width of breast streaks varies from 1.5 to $3.0 \mathrm{~mm}$ in the northern region, from 1.0 to $3.0 \mathrm{~mm}$ in the central region, and from 1.0 to $1.5 \mathrm{~mm}$ in the southern region (Figure 2). The Kolmogorov-Smirnov test indicates significant differences between northern and southern populations $(D=0.82, P<0.001)$ and between 
Table 1. Measurements of specimens of Moustached Woodcreepers separated into three major regions and results from ANOVA

\begin{tabular}{lccccc}
\hline Regions & Wing & Tail & Bill & Total culmen & Tarsus \\
\hline Northern & $130.0(6.4)$ & $106.5(6.9)$ & $39.3(1.3)$ & $51.8(1.3)$ & $27.5(2.8)$ \\
& $113.0-140.0$ & $99.5-120.0$ & $36.0-42.0$ & $48.0-54.0$ & $23.5-32.0$ \\
Central & 17 & 16 & 16 & 16 & 17 \\
& $130.1(5.2)$ & $109.0(7.3)$ & $39.2(1.3)$ & $52.0(1.5)$ & $26.9(1.8)$ \\
& $121.0-138.0$ & $99.0-122.0$ & $37.0-41.0$ & $50.0-55.0$ & $25.0-30.0$ \\
Southern & 7 & 7 & 7 & 7 & 7 \\
& $130.0(4.9)$ & $101.5(2.9)$ & $40.7(2.0)$ & $53.6(2.0)$ & $26.1(1.2)$ \\
& $125.0-139.0$ & $96.0-107.0$ & $38.0-43.0$ & $50.0-59.0$ & $24.0-29.0$ \\
ANOVA & 15 & 15 & 16 & 16 & 16 \\
& $F_{2,36}=0.004$ & $F_{2,35}=5.05$ & $F_{2,36}=4.99$ & $F_{2,36}=5.06$ & $F_{2,37}=1.02$ \\
\hline
\end{tabular}

First row: mean and standard deviation (in parentheses). Second row: range. Third row: number of specimens. In ANOVA results; n.s. not significant (i.e. $P>0.05$ ).

central and southern populations $(\mathrm{D}=0.714, P<0.05)$, but not between northern and central populations $(D=0.36$, n.s.).

\section{Body measurements}

Among the five body measurements examined, three (tail, exposed culmen and total culmen) showed significant differences among the three regions (Table 1). Tukey's test indicated that individuals from the southern population have a tail significantly shorter than those from the northern $(P<0.05)$ and central $(P<0.05)$ populations. No significant difference was found between northern and central populations. Tukey's test indicates a similar pattern in the variation of exposed culmen and total culmen, as significant differences in these body measurements were found only between northern and southern populations (exposed culmen: $P<0.05$; total culmen: $P<0.01$ ). Because northern and central populations did not show any significant difference in all five body measurements, we pooled specimens of these two regions and compared them with specimens of the southern region by using the linear discriminant analysis. Of the 22 specimens from region northern + central examined, $16(73.0 \%)$ were classified correctly in this region. Of the 15 specimens from the southern region, $10(67.0 \%)$ were classified correctly.

\section{Discussion}

Are falcirostris and franciscanus different subspecies?

Three characters have been pointed out as useful in separating franciscanus from falcirostris (Meyer de Schauensee 1970, Teixeira 1990, Ridgely and Tudor 1994): (a) underparts coloration, (b) width of the breast streaks, and (c) the amount of streaks in the crown. On average, specimens from the southern region (franciscanus) have darker underparts than those from the northern and central populations (falcirostris). However, there are five specimens of 
falcirostris $(n=23,21.7 \%)$ that are as dark as most individuals of franciscanus. Specimens of falcirostris have also, on average, breast streaks wider than specimens of franciscanus but there are five specimens $(21.7 \%)$ from different parts of the range of falcirostris whose measurements are within the variation found in franciscanus. The amount of streaking in the crown also shows some overlap, as five specimens of franciscanus $(27.7 \%)$ exhibit the same pattern found in most specimens of falcirostris. Only one body measurement (tail) indicated significant differences between the group formed by northern + central populations (falcirostris) and the southern population (franciscanus). Body measurements when submitted to linear discriminant analysis were useful to identify correctly $73.0 \%$ of the individuals of franciscanus and $67.0 \%$ of the specimens of falcirostris.

No single plumage character or body measurement alone can be used to separate at a reasonable level (i.e., 90\%, cf. Amadon and Short 1992) franciscanus from falcirostris. However, by combining characters such as darkness of underparts, width of breast streaks and the amount of streaks in the head, diagnosability may be achieved. If so, falcirostris and franciscanus can be formally recognized as different subspecies under the biological species concept (Mayr 1969). However, for conservation purposes, subspecies are only useful if they indeed represent populations that, although showing reproductive compatibility, have accumulated unique genes or gene combinations indicating an independent evolutionary history to that of their sister taxon/taxa (i.e. they are phylogenetic species, Zink and McKitrick 1995). In this regard, molecular studies are indispensable to test the hypothesis that plumage differences found in falcirostris and franciscanus indeed indicate significant genetic differences. Given the conservation importance of this bird, we suggest that the currently accepted division of X. falcirostris into X. f. falcirostris and X. f. franciscanus be maintained until the definitive answer to the taxonomic question is provided by genetic studies.

\section{Plumage variation in Moustached Woodcreepers}

We have found that the qualitative plumage variation among the specimens from the northern and central regions is greater than that among specimens from the southern region. This large plumage variation in northern and central populations is so conspicuous at a first glance that Pinto and Camargo (1961), after analysing the series deposited in the MZUSP, went so far as to suggest the possibility that an undescribed subspecies constituted part of the collection. A single hypothesis to explain this pattern may be proposed if we contrast the pattern of spatial distribution between these two groups of populations. Northern and central populations are found only in enclaves of tropical dry (semi-deciduous or deciduous) forests that are isolated by the xeric and open caatinga vegetation (Andrade-Lima 1982). Therefore, one could expect to find a tendency toward a high degree of phenotypic variation among these isolated populations, possibly as a consequence of genetic drift and the limited gene flow among populations. In contrast, the tendency in the southern population should be rather different, as its range encompasses an extensive area of continuous tropical dry deciduous forests that is associated with rich soils derived from 
limestone rocks (Azevedo 1966, Ratter et al. 1978, EMBRAPA 1986). In this way, the homogenizing action of gene flow could explain why plumage variation within the southern population is much less accentuated than that observed in the set composed of northern and central populations.

\section{Conservation}

Our field studies demonstrated that the Moustached Woodcreeper is an excellent indicator species of intact and slightly disturbed tropical dry forests in north-eastern Brazil. This is one of the South American habitats whose biological resources are most poorly known. Recent studies have indicated that this special type of vegetation harbours a very distinctive set of endemic and characteristic species of plants (Ratter et al. 1978, Prado and Gibbs 1993) and animals (Silva 1989, Silva and Oren 1992, 1993). The few remaining enclaves of tropical dry forests in north-eastern Brazil are highly threatened by human activity. Since these forests grow on relatively rich soils, they are prime candidates for clearing for both irrigated and dry field agriculture. Furthermore, the high biomass of these forests make them important sources of fuel for Brazil's steel and pig iron industries, which run entirely on charcoal. Although hundreds of thousands of hectares of eucalyptus plantations have been planted to supply charcoal for these industries, the recent rise in the value of these same eucalyptus plantations as sources of pulp for paper manufacture has meant that the eucalyptus trees originally planted as substitutes for native forest charcoal are now being cut for the paper pulp industry (G. Fonseca, verbally to D. C. O.). This increases pressure on the few remaining native forests for charcoal. A drastic example of how fast the destruction of dry forests is taking place is that a large and undisturbed tropical dry forest patch (Coribe, Bahia) where Moustached Woodcreepers were abundant in 1988 had been entirely destroyed when it was visited again in 1993 (J.M.C.S., unpubl. data). Furthermore, international financing agencies (World Bank and Interamerican Development Bank, for example) have accelerated the destruction rate by underwriting new irrigation projects in the southern region. The environmental impact studies for these projects usually do not take into account the rich and highly endangered biodiversity of the deciduous forests that they destroy.

We estimate that under the current levels of destruction, very little (less than $5 \%$ ) of the tropical dry forests in north-eastern Brazil will survive in the next 5 years. The only feasible alternative to guarantee the conservation of at least part of this unique type of vegetation is to implement an urgent plan that should include the following steps: (a) temporarily ban (c. 10 years) any type of human alteration in this habitat; (b) promote the mapping and ecological evaluation of the patches of dry forests still extant; (c) create, after such studies, a system of conservation units that maximizes the representation of the original fauna and flora; and (d) promote in those areas not included in the conservation units long-term studies on different aspects of the ecology of tropical dry forests (e.g. succession, influence of selective logging on the fauna and flora) with the goal of developing viable strategies for future economic utilization. In this context, the Moustached Woodcreeper, an 
excellent indicator species, can be used to help identify the most important enclaves of north-eastern Brazilian tropical dry forest that need to be preserved. Based on our field experience in the last to years with tropical dry forests in north-eastern Brazil, we suggest that the following regions could be regarded as a priority for studies that seek the creation of new reserves: (a) left bank of the River São Francisco, from Barra, Bahia, to Itacarambi, Minas Gerais, including patches along the Grande and Preto Rivers in north-western Bahia; (b) southern Piauí; and (c) south-central Maranhão.

\section{Acknowledgements}

We thank J. Fjeldså, M. E. Petersen, D. Stotz and R. B. Cavalcanti for critical review that greatly improved the first draft of this paper. F. C. Novaes helped us very much during the development of this project. For companionship and help during field work we thank D. C. Pimentel Neto, S. F. Balbino, J. Ribeiro, J. N. Santa Brígida, M. S. Brígida, and A. Teixeira. We thank Mr. José de Paula (Itacarambi) and the staff of CODEVASF in Santa Maria da Vitória for their help during our studies in the São Francisco River valley. D. M. Teixeira and J. B. Nacinovic (MNRJ), H. F. A. Camargo (MZUSP), and M. LeCroy and G. Barrowclough (AMNH) provided us with all facilities to study the collections under their care. Our studies were supported by a doctoral scholarship (J.M.C.S.) and a fellowship (D.C.O.) of the Conselho Brasileiro de Desenvolvimento Científico e Tecnológico $(\mathrm{CNPq})$. Financial support for field work and collection studies came from National Geographic Society (Grant no. 4964-93), The Frank M. Chapman Memorial Fund, World Wildlife Fund-US, The John D. and Catherine T. MacArthur Foundation, Danish Natural Science Research Council (Grant J.no. 11-039o), Museu Paraense Emílio Goeldi/ $\mathrm{CNPq} / \mathrm{MCT}$, and Universidade de Brasília.

\section{Appendix. List of specimens examined.}

$X$. falcirostris falcirostris.

MARANHÃO: Mangueiras, Flores, 2 males and 2 females; Tuntun, 1 female; Sambaíba, 1 male.

PIAUÍ: Belo Horizonte, 1 male; Corrente, 2 males; Teresina, 2 males; São Luis, 1 male.

CEARÁ: Açudinho, 1 female; Joazeiro, 1 female; Ijuí, 1 female.

PARAIBA: Coremas, 2 females.

PERNAMBUCO: Nova Floresta, Fazenda Campos Belos, I female. BAHIA: Santa Rita do Rio Preto, 1 female and 2 males; Cantinho do Rio Preto, 2 males.

$X$. f. franciscanus.

MINAS GERAIS: Januária, Brejo Januária (now Brejo do Ambraro), 1 male; Itacarambi, Fazenda Olho D'água, 6 males and 2 females.

BAHIA: Coribe, Fazenda Formoso, 6 males and 3 females.

GOIÁS (?): Posse (?), 1 specimen of unknown sex.

\section{References}

Ab'Saber, A. N. (1977) Os Domínios morfoclimáticos da América do Sul. Primeira Aproximação. Geomorfologia 52: 1-21. 
Amadon, D. and Short, L. (1992) Taxonomy of lower categories: suggested guidelines. Bull. Brit. Orn. Club 112A: 11-38.

Andrade-Lima, D. (1982) The caatingas dominium. Rev. bras. Bot. 4: 149-153.

Azevedo, L. G. (1966) Tipos eco-fisionômicos da vegetação da região de Januária (MG). Anais Acad. bras. Ciênc. 38 (Suppl.): 39-57.

Baldwin, S. P., Oberholser, H. C. and Worley, L. G. (1931) Measurements of birds. Sci. Publ. Cleveland Mus. of Nat. Hist. 2: 1-165.

Bernardes, A. T., Machado, A. B. M. and Rylands, A. B. (1990) Fauna brasileira ameaçada de extinção. Belo Horizonte: Fundação Biodiversitas para a Conservação da Diversidade Biológica.

Collar, N. J., Gonzaga, L. P., Krabbe, N., Madroño Nieto, A, Naranjo, L. G., Parker III, T. A. and Wege, D. C. (1992) Threatened birds of the Americas. Cambridge, U.K.: International Council for Bird Preservation.

EMBRAPA. Serviço Nacional de Levantamento e Conservação de solos. (1986) Levantamento exploratório-reconhecimento de solos da margem esquerda do rio São Francisco, Estado da Bahia. Boletim Técnico (EMBRAPA-SNLCS) 38: 1-404.

Forshaw, J. M. (1978) Parrots of the world. Melbourne: Lansdowne Press.

Hellmayr, C. E. (1906) Revision der Spix'schen Typen brasilianischer Vögel. Abhandl. Königl. Bayer. Akad. Wissensch. 22:561-726.

Hellmayr, C. E. (1929) A contribution to the ornithology of northeastern Brazil. Field Mus. Nat. Hist., Zool. Ser., 13: 1-258.

Mayr, E. (1969) Principles of systematic zoology. New York: McGraw-Hill.

Meyer de Schauensee, R. (1966) The species of birds of South America and their distribution. Narberth: Livingston.

Meyer de Schauensee, R. (1970) A guide to the birds of South America. Wynnewood: Livingston.

Minitab Inc. (1991) Minitab 8.o. PC version, reference manual. State College: Minitab.

Peters, J. L. (1951) Checklist of birds of the world, vol. 7. Cambridge, Mass.: Museum of Comparative Zoology.

Pinto, O. M. O. (1952) Súmula histórica e sistemática da ornitologia de Minas Gerais. Arq. Zool. São Paulo 8: 1-51.

Pinto, O. M. O. (1978) Novo Catálogo das Aves do Brasil. São Paulo: Editora Gráfica dos Tribunais.

Pinto, O. M. O. and Camargo, E. A. (1961) Resultados ornitológicos de quatro recentes expedições do Departamento de Zoologia ao nordeste do Brasil, com a descrição de seis novas subespécies. Arq. Zool. São Paulo 13: 51-69.

Prado, D. E. and Gibbs, P. E. (1993) Patterns of species distributions in the dry seasonal forests of South America. Ann. Missouri Bot. Gard. 80: 902-927.

Ratter, J. A., Askew, G. P., Montgomery, R. F. and Gifford, D. R. (1978) Observations on forests of some mesotrophic soils in central Brazil. Rev. bras. Bot. 1: 47-58.

Ridgely, R. S. and Tudor, G. (1994) The birds of South America, vol. 2. Oxford: Oxford University Press.

Sick, H. (1985) Ornitologia brasileira: uma introdução. Brasília: Editora Universidade de Brasília.

Silva, J. M. C. (1989) Análise biogeográfica da avifauna das florestas do interflúvio Araguaia-São Francisco. M.Sc. dissertation, University of Brasília.

Silva, J. M. C. and Oren, D. C. (1992) Notes on Knipolegus franciscanus Snethlage, 1928 (Aves: Tyrannidae), an endemism of central Brazilian dry forests. Goeldiana Zoologia 16: $1-9$.

Silva, J.M.C. and Oren, D.C. (1993) Observations on the habitat and distribution of the Brazilian three-banded armadillo (Tolypeutes tricinctus), a threatened Caatinga endemic. Mammalia 57: 149-152. 
Smithe, F. B. (1974) Naturalist's color guide. New York: American Museum of Natural History.

Smithe, F. B. (1981) Naturalist's color guide. Part II. New York: American Museum of Natural History.

Snethlage, E. (1926) Uma nova espécie de dendrocolaptídeo no interior do Brasil. Bol. Mus. Nac. 3: $59-60$.

Spix, J. B. (1824) Avium species novae Brasilian. München: Hubschmann.

Teixeira, D. M. (1990) Notas sobre algumas espécies descritas por Emile Snethlage. Bol. Mus. Nac. Rio de Janeiro, n.s. Zool, 331: 1-6.

Teixeira, D. M. , Nacinovic, J. B. and Luigi, G. (1989) Notes on some birds of northeastern Brazil (4). Bull. Brit. Orn. Club 109: 75-79.

Zar, J. H. (1984) Biostatistical Analysis. Englewood Cliffs, N.J.: Prentice Hall.

Zink, R. M. and McKitrick, M. C. (1995) The debate over species concept and its implications for ornithology. Auk 112: 701-719.

JOSÉ MARLA CARDOSO DA SILVA

Zoological Museum, University of Copenhagen, Universitetsparken 15DK-2100, Copenhagen, Denmark.

\section{DAVID C. OREN}

Museu Paraense Emilio Goeldi, Departamento de Zoologia, C.P. 399, 66017-940, Belém, PA, Brazil. 